\section{RSP}

http://www.rsp.fsp.usp.br/
Revista de Saúde Pública

\title{
Tuberculosis as a marker of inequities in the context of socio-spatial transformation
}

Alexandre San Pedro', Gerusa Gibson", Jefferson Pereira Caldas dos Santos', Luciano Medeiros de Toledo', Paulo Chagastelles Sabroza', Rosely Magalhães de Oliveira'

Departamento de Endemias Samuel Pessoa. Escola Nacional de Saúde Pública. Fundação Oswaldo Cruz. Rio de Janeiro, RJ, Brasil

" Instituto de Estudos em Saúde Coletiva. Universidade Federal do Rio de Janeiro. Rio de Janeiro, RJ, Brasil

\section{ABSTRACT}

OBJECTIVE: This study aims to analyze the association between the incidence of tuberculosis and different socioeconomic indicators in a territory of intense transformation of the urban space.

METHODS: This is an ecological study, whose analysis units were the neighborhoods of the city of Itaboraí, state of Rio de Janeiro, Brazil. The data have been analyzed by generalized linear models. The response variable was incidence of tuberculosis from 2006 to 2011. The independent variables were the socio-demographic indicators. The spatial distribution of tuberculosis was analyzed with the elaboration of thematic maps.

RESULTS: The results have shown a significant association between the incidence of tuberculosis and variables that reflect different dimensions of living conditions, such as consumer goods, housing conditions and its surroundings, agglomeration of population, and income distribution.

CONCLUSIONS: The disproportionate incidence of tuberculosis in populations with worse living conditions highlights the persistence of socioeconomic determinants in the reproduction of the disease. Different municipal public sectors need to better articulate with local tuberculosis control programs to reduce the social burden of the disease.

DESCRIPTORS: Tuberculosis, epidemiology. Socioeconomic Factors. Health Inequalities. Social Inequity. Ecological Studies. 


\section{INTRODUCTION}

Among the individual and contextual determinants related to tuberculosis, socioeconomic conditions are seen as important factors associated with the reproduction of the disease $e^{4,9,12,15,18}$. Tuberculosis operates as a marker of social inequities in health linked to precarious living conditions. That is why the World Health Organization has listed the reduction of the socioeconomic burden of the disease as one of the most important goals to be achieved until $2015^{\mathrm{a}}$.

However, the focus of programmatic activities that are predominantly fixated on the identification and timely treatment of cases, as well as the lack of dialog with other government sectors, limits the scope of municipal control programs for the reduction of the social burden of the disease. Such a situation can be exacerbated in territories undergoing an important process of transformation of urban space induced by the implementation of major economic development projects. The expectation of increased land values, increased economic inequalities and deepened social division, in addition to other factors such as the arrival of a migrant population with a low degree of technical training and little prospect of integration into the formal economy circuit ${ }^{1}$, can exert strong influence on the reproduction of tuberculosis.

The city of Itaboraí, State of Rio de Janeiro, Brazil, has a history of high incidence of tuberculosis and it is undergoing important transformations of its urban space to host the largest petrochemical complex in the Latin America. The city suffers significant transformations in its urbanization pattern since the beginning of the implementation of the project in 2008, with an increase in housing informality and in the precariousness of housing conditions arising from deprivation of environmental sanitation ${ }^{\mathrm{b}}$. The number of households in precarious settlements increased $79.0 \%$ between 2000 and 2010, concurrently with the increase in land values since the enunciation of the implementation of the project in the city ${ }^{\mathrm{b}, \mathrm{c}}$.

The rapid process of socio-spatial reorganization of the region results in the formation of conflicting territorial arrangements in which urban patterns with appropriate infrastructure and services live next to spaces marked by housing informality and precarious urban infrastructure ${ }^{1}$. This demand a high adaptive and analytical capacity from local control programs regarding the ongoing changes in the epidemiological situation of the disease.

The importance of socioeconomic factors related to the process of reproduction of tuberculosis in intra-urban agglomerations is known ${ }^{5,15,19}$. Nevertheless, little progress has been made in the discussion of socio-spatial patterns related to the evolution of the disease in contexts under intense transformation, as in Itaboraí. This study has aimed to analyze the relationship between the occurrence of tuberculosis and different socioeconomic dimensions linked to the living conditions of an endemic city undergoing a process of transformation of its urban space.

\section{METHODS}

This is an ecological study, whose analysis units were the seventy-nine neighborhoods of Itaboraí. The city is located in the region Leste Fluminense, $46 \mathrm{~km}$ from the city of Rio de Janeiro. The association between the incidence of tuberculosis from 2006 to 2011 and the socioeconomic indicators related to the neighborhoods of the city were analyzed by generalized linear models.

Historically, Itaboraí is characterized by its importance in the economic dynamics of the region in which it is inserted. In the colonial period, it was considered the main trading post of the sugar production of Eastern Baixada da Guanabara, a place of convergence of herdsmen transporting the sugar and coffee production from neighboring 
dMachado LO. Diagnóstico socioeconômico da Bacia do Caceribu: gente de Caceribu, sua geografia, sua história. 1998 [cited 2015 Oct 20]. Available from: http://acd.ufrj.br/fronteiras/ trabtec/caceribu.htm

e Instituto Brasileiro de Geografia e Estatística. Censo 2010. Rio de Janeiro: IBGE [cited 2015 Oct 20]. Available from: http://www. censo2010.ibge.gov.br/resultados ${ }^{\mathrm{f}}$ Programas das Nações Unidas para o Desenvolvimento. Atlas de desenvolvimento humano no Brasil. 2013 [cited 2015 Oct 20]. Available from em: http://www. pnud.org.br/IDH/Atlas2013. aspx?indiceAccordion $=1 \& \mathrm{li}=\mathrm{li}$ Atlas2013

${ }^{g}$ Barbosa SQ. As práticas educativas em saúde relacionadas à tuberculose: estudo de caso em uma unidade de saúde da família no município de Itaboraí [dissertation]. Rio de Janeiro (RJ): Escola Nacional de Saúde Pública, Fundação Oswaldo Cruz; 2012. regions to the city of Rio de Janeiro ${ }^{\mathrm{d}}$. Currently, it has strategic importance for the economic development of the State of Rio de Janeiro and even Brazil, as it hosts the largest petrochemical industrial complex of Latin America. With the beginning of the implementation of the Petrochemical Complex of Rio de Janeiro (COMPERJ) in 2008, the city started experiencing a significant transformation of its urban space. Economic activities proliferated, aimed at the service and real estate speculation sectors, with expectations of increased migratory flow after the implantation of downstream petroleum industries.

Itaboraí had a census population of 218,000 inhabitants in 2010, with its Municipal Human Development Index (MHDI) being considered as intermediate (0.69), in addition to a monthly average income of $\mathrm{R} \$ 1,860$, and Gini index reflecting reasonable inequality of income distribution $(0.48)^{\mathrm{e}, \mathrm{f}}$.

The tuberculosis control program has been decentralized since 2003. That year, the strategy Tratamento Diretamente Observado (TDO - Directly Observed Treatment) was implemented in thirty-four Family Health Units (FHU), responsible for forty-five teams of the Family Health Strategy (FHS), whose percentage of territorial coverage was approximately $77.0 \%^{\mathrm{g}}$. The strategy of the TDO was extended to patients not covered by the FHS in 2005, and important results were achieved in the five-year period, such as the reduction from $30.0 \%$ to $5.0 \%$ in the abandonment of the treatment and increase from $60.0 \%$ to $88.0 \%$ in the percentage of cases cured ${ }^{16}$. Despite these important results, Itaboraí is one of the 181 priority Brazilian cities for the control of the disease as it presents incidence rates above $80.0 \%$ of the estimated rate for the country ( 32 new cases /100,000 inhabitants) ${ }^{6}$ since 2007.

The study sample consisted of new cases of pulmonary tuberculosis registered in the Sistema Nacional de Agravos de Notificação (SINAN - Notifiable Diseases Information System) from 2006 to 2011. We organized the cases according to the neighborhood of residence. For the records that had no information about the neighborhood, we crossed the street address with the registration of streets and land developments of the neighborhoods provided by the Local Government, resulting in completeness of $93.4 \%$ for this variable. We obtained the socioeconomic data used for the construction of indicators from the 2010 Census of the Brazilian Institute of Geography and Statistics (IBGE) and aggregates for the territorial level of neighborhoods. We based the population estimates for the intercensal period on the geometric growth model, assuming constant linear variation per unit of time (year).

The criteria for the initial selection of indicators considered the importance in determining the production and living conditions of tuberculosis, based on a study of systematic review ${ }^{15}$ on the topic, as well as the availability of data in the 2010 Census. We did not seek the directionality of the indicators a priori; on the contrary, we wanted a broader analysis of the relationship between socioeconomic inequality and occurrence of tuberculosis. We constructed indicators grouping them according to different dimensions of living conditions (Table 1).

The response variable was the number of cases of pulmonary tuberculosis according to the neighborhoods of Itaboraí between 2006 and 2011. We analyzed the data by generalized linear model (GLM) with Poisson distribution. However, we decided to use GLM with negative binomial distribution because of the great dispersion of the multiple final model ${ }^{8}$.

The model used assumes the form $\log (\mu)=\beta \mathrm{x}$ (log link function), where $\mathrm{x}_{\mathrm{i}}$ is the explanatory variable. The population was included as offset level considering its logarithm of each neighborhood. The exponential of regression coefficients $\beta_{i}$ represents the Incidence Rate Ratio (IRR) ${ }^{9}$. We tested the explanatory variables separately. Those that showed statistical significance $(p<0.20)$ were included, one by one, in the negative binomial regression with log link function (forward method). Before the 
analysis, we tested for multicollinearity using VIF (Variance Inflation Factor) among the independent variables, with tolerance of less than ten. We selected the multiple model with best fit by the likelihood ratio test ${ }^{8}$, which consists of a hypothesis test that compares the quality of fit between two models, in which one of the models is the subset of the other (nested models). We used Moran's I index for spatial autocorrelation in the residuals from the final multiple model.

We carried out a descriptive analysis of the spatial distribution of tuberculosis from thematic maps of the average incidence by neighborhoods for the times related to the period of enunciation and beginning of works (2006 to 2008) and the period in which the installation process of the projects was intensified (2009 to 2011). To compare the periods, we divided the classes by quartile from the set of rates (2006 to 2011), which were smoothed by the Empirical Bayes method, assuming a matrix of neighborhood by contiguity. We decided to smooth in this step because of the neighborhoods with small population, as they result in greater instability of the estimated gross rates.

This study was carried out according to the determinations of the Research Ethics Committee of the Escola Nacional de Saúde Pública Sergio Arouca (Opinion 71,237/2012).

Table 1. Selected socioeconomic variables according to different dimensions of living conditions.

\begin{tabular}{|c|c|c|}
\hline Dimensions & Variables & Description \\
\hline \multirow{2}{*}{ Consumer goods } & Private vehicle & Percentage of households with private vehicle \\
\hline & Microcomputer & Percentage of households with microcomputer \\
\hline \multirow{2}{*}{$\begin{array}{l}\text { Health } \\
\text { infrastructure }\end{array}$} & Supply of Water & $\begin{array}{l}\text { Percentage of households connected to the general network of } \\
\text { water supply and indoor plumbing in at least one room }\end{array}$ \\
\hline & Sewage system & $\begin{array}{c}\text { Percentage of households connected to the general network of } \\
\text { rainwater or sewage system }\end{array}$ \\
\hline \multirow{5}{*}{$\begin{array}{l}\text { Housing } \\
\text { conditions and } \\
\text { surroundings }\end{array}$} & Coating of exterior walls & Percentage of households without coating on the external walls \\
\hline & $\begin{array}{l}\text { Identification of the street } \\
\text { address }\end{array}$ & $\begin{array}{l}\text { Percentage of households without identification of street } \\
\text { address }\end{array}$ \\
\hline & Open sewer & Percentage of households with open sewer in the surroundings \\
\hline & Street lighting & $\begin{array}{c}\text { Percentage of households without street lighting in the } \\
\text { surroundings }\end{array}$ \\
\hline & Accumulated waste & $\begin{array}{c}\text { Percentage of households with accumulated waste in the } \\
\text { surroundings }\end{array}$ \\
\hline \multirow[t]{2}{*}{ Income } & $\begin{array}{l}\text { Proportion of poor } \\
\text { persons }\end{array}$ & $\begin{array}{l}\text { Percentage of heads of household with income up to one } \\
\text { minimum wage }\end{array}$ \\
\hline & Theil Index & Inequality in income distribution of the heads of household ${ }^{a}$ \\
\hline Education & Education level & Percentage of heads of household with incomplete High School \\
\hline \multirow[b]{2}{*}{ Social assistance } & $\begin{array}{l}\text { Social security } \\
\text { contribution }\end{array}$ & $\begin{array}{l}\text { Percentage of taxpayers with official social security in their } \\
\text { main job or in another job }\end{array}$ \\
\hline & $\begin{array}{l}\text { Government financial } \\
\text { benefits }\end{array}$ & $\begin{array}{c}\text { Percentage of beneficiaries of the Social Program Bolsa Familia } \\
\text { or Programa de Erradicação de Trabalho Infantil (Program on } \\
\text { the Elimination of Child Labor) }\end{array}$ \\
\hline \multirow{3}{*}{$\begin{array}{l}\text { Population } \\
\text { agglomeration }\end{array}$} & Population density & Number of inhabitants according to total usable area by km²b \\
\hline & Density of the poor & $\begin{array}{l}\text { Number of heads of domicile with income up to one minimum } \\
\text { wage according to total usable area by } \mathrm{km}^{2}\end{array}$ \\
\hline & Density per room & $\begin{array}{l}\text { Percentage of households with more than three residents per } \\
\text { room }\end{array}$ \\
\hline \multirow{2}{*}{ Migration } & New immigrants & $\begin{array}{c}\text { Percentage of persons who immigrated between one and two } \\
\text { years before the } 2010 \text { Census }\end{array}$ \\
\hline & Old immigrants & $\begin{array}{c}\text { Percentage of persons who immigrated more than ten years } \\
\text { before the } 2010 \text { Census }\end{array}$ \\
\hline
\end{tabular}

a Souza PFL, Salvato MA. Decomposição hierárquica da desigualdade de renda brasileira. In: XXXVI Encontro Nacional de Economia. 2008, Salvador - Bahia. Anais do XXXVI Encontro Nacional de Economia. 2008. p.1-21. Available from: http://www.anpec.org.br/encontro2008/artigos/200807211123470-.pdf

${ }^{\mathrm{b}}$ Buildable portion of the neighborhood, estimated by the merged image of the sensors PRISM (Panchromatic Remote-sensing Instrument for Stereo Mapping) and AVINIR (Advanced Visible and Near Infrared Radiometer type 2) of the satellite ALOS (Advanced Land Observing Satellite). 


\section{RESULTS}

Eight hundred and four new cases of pulmonary tuberculosis were reported in Itaboraí from 2006 to 2011, with an annual average of 134 cases ( $\min .=103$, $\max =158$ ) and average annual rate of incidence of 64.4 cases per 100,000 inhabitants. Table 2 presents the measures of central tendency and dispersion of the indicators according to the neighborhoods of Itaboraí.

Regarding the spatial distribution of the disease, neighborhoods with higher rates in the first period were located in the two main urban axes of the city (Southwest and Center). On the other hand, the second period (2009 to 2011) suggested a reduction of rates in the neighborhoods located in these urban axes, but with persistence in some neighborhoods with higher densities of poor persons (Figure - A, B, C). The proximity to the main highways that go through Itaboraí was a common characteristic between the territorial units with higher rates of the disease in both periods analyzed.

The univariate analysis between incidence of tuberculosis and socioeconomic indicators pointed to significant association with variables related to living conditions (Table 3).

We have observed inverse associations between incidence of tuberculosis and the variables related to consumer goods and direct associations with variables related to housing conditions and surroundings and appropriate infrastructure (Table 3).

We have observed inverse association between incidence of tuberculosis and percentage of social security taxpayers and direct association with percentage of beneficiaries of income transfer programs. The greater inequality of income distribution, measured by the Theil index, was directly associated with occurrence of tuberculosis (Table 3).

Table 2. Measure of central tendency (arithmetic mean) and dispersion of socioeconomic indicators preselected in the univariate analysis, according to neighborhoods. Itaboraí, RJ, Southeastern Brazil, 2010.

\begin{tabular}{|c|c|c|c|}
\hline Dimensions of living conditions and socioeconomic indicators & Mean & $\begin{array}{l}\text { Standard } \\
\text { deviation }\end{array}$ & Min.-Max. \\
\hline \multicolumn{4}{|l|}{ Consumer goods } \\
\hline Households with microcomputer & 29.9 & 11.3 & $7.8-66.0$ \\
\hline Households with private vehicle & 29.3 & 12.1 & $6.1-58.0$ \\
\hline \multicolumn{4}{|l|}{ Housing conditions } \\
\hline Households without coating on the external walls & 19.1 & 10.8 & $0-42.8$ \\
\hline Households connected to the general sewage network & 27.6 & 26.1 & $5.05-84.7$ \\
\hline Households without identification of street address & 39.8 & 21.4 & $2.7-85.4$ \\
\hline Households with open sewer in the surroundings & 16.1 & 14.5 & $0-37.8$ \\
\hline \multicolumn{4}{|l|}{ Social assistance } \\
\hline Social security taxpayers & 60.6 & 11.4 & $33.7-92.3$ \\
\hline $\begin{array}{l}\text { Beneficiaries of government cash transfer programs (Bolsa Família or } \\
\text { Program on the Elimination of Child Labor) }\end{array}$ & 6.9 & 3.5 & $0-15.7$ \\
\hline \multicolumn{4}{|l|}{ Income distribution } \\
\hline Theil Index & 0.4 & 0.1 & $0.2-0.6$ \\
\hline \multicolumn{4}{|l|}{ Density } \\
\hline Density of the poor & 292 & 271.2 & $20-1,084$ \\
\hline Population density & $1,834.0$ & $1,775.8$ & $102-6,050$ \\
\hline Households with more than three residents per room & 9.1 & 4.6 & $1.0-21.3$ \\
\hline \multicolumn{4}{|l|}{ Migration } \\
\hline Migrant between one and two years before the Census & 4.9 & 2.6 & $0-11.6$ \\
\hline Migrant for more than ten years before the Census & 28.3 & 10.1 & $7.3-50.9$ \\
\hline
\end{tabular}

Note: The socioeconomic variables have been expressed as percentage. 
(A)

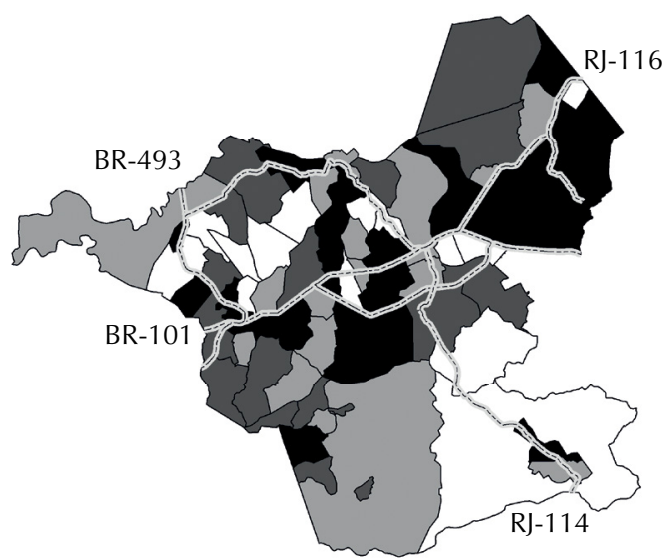

- Highways

Neighborhoods of Itaboraí

Smoothed incidence rate (2006-2008)

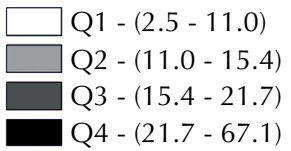

(B)

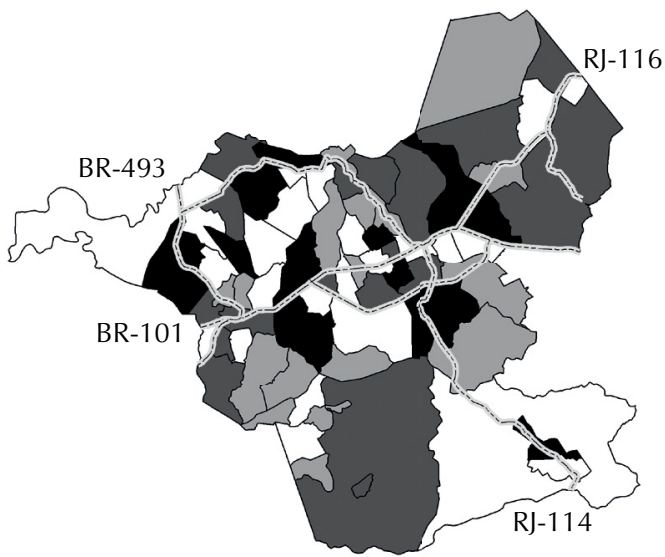

Highways

Neighborhoods of Itaboraí

Smoothed incidence rate (2009-2011)

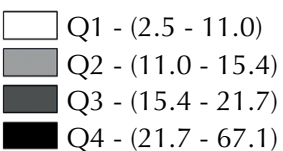

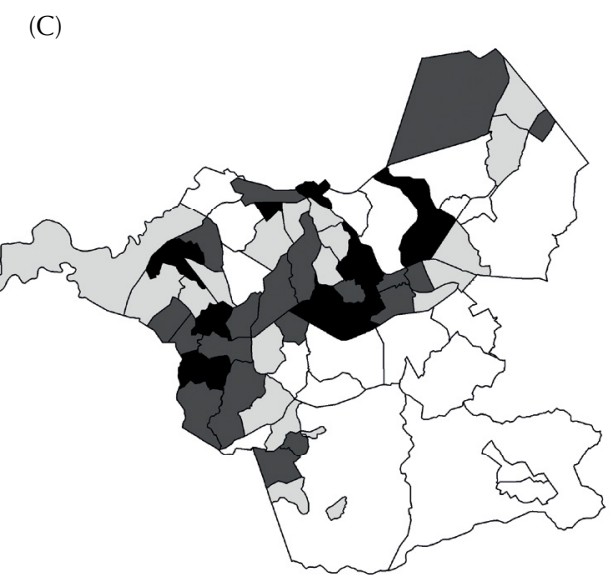

Neighborhoods of Itaboraí

Density of the poor

Q1 - (3 - 37)

Q2 - (37 - 148)

Q3 - (148 - 354)

Q4 - (354 - 1083)

Figure. (A) Spatial distribution of tuberculosis according to neighborhoods. Itaboraí, RJ, Southeastern Brazil, from 2006 to 2008; (B) Spatial distribution of tuberculosis according to neighborhoods. Itaboraí, RJ, Southeastern Brazil, from 2009 to 2011; (C) Spatial distribution of the indicator "density of the poor" according to neighborhoods. Itaboraí, RJ, Southeastern Brazil, 2010.

We have also observed direct association with recent migration and population agglomeration in the territory and density per room (Table 3).

The model with best fit in the multiple analysis had these variables: percentage of households with private vehicle, percentage of households with more than three residents per room, percentage of households with presence of open sewer in the surroundings, density of the poor, Theil index and percentage of recent migrants (Table 3).

Moran's I index, related to the residuals of the final multiple model, showed no statistical significance $(p=0.483)$, thus indicating the absence of spatial autocorrelation. 
Table 3. Parameters of the univariate analysis and multiple model with the respective tuberculosis incidence rate ratios according to neighborhoods. Itaboraí, RJ, Southeastern Brazil, 2006 to 2011.

\begin{tabular}{|c|c|c|c|}
\hline Dimensions of living conditions and socioeconomic indicators & IRR & $95 \% \mathrm{Cl}$ & $p$ \\
\hline \multicolumn{4}{|l|}{ Consumer goods } \\
\hline Households with microcomputer & 0.73 & $0.55-0.98$ & 0.03 \\
\hline Households with private vehicle & 0.63 & $0.49-0.82$ & 0.00 \\
\hline \multicolumn{4}{|l|}{ Availability of health infrastructure } \\
\hline Households connected to the general sewage network & 1.64 & $1.48-1.81$ & 0.00 \\
\hline \multicolumn{4}{|l|}{ Housing conditions and surroundings } \\
\hline Households without coating on the external walls & 1.82 & $1.56-2.13$ & 0.00 \\
\hline Households without identification of street address & 1.25 & $1.08-1.45$ & 0.00 \\
\hline Households with open sewer in the surroundings & 1.51 & $1.32-1.73$ & 0.00 \\
\hline \multicolumn{4}{|l|}{ Social assistance } \\
\hline Social security taxpayers & 0.43 & $0.20-0.89$ & 0.00 \\
\hline $\begin{array}{l}\text { Beneficiaries of government cash transfer programs (Bolsa Família or Program } \\
\text { on the Elimination of Child Labor) }\end{array}$ & 2.20 & $1.68-2.86$ & 0.00 \\
\hline \multicolumn{4}{|l|}{ Income distribution } \\
\hline Theil Index & 1.95 & $1.06-3.60$ & 0.03 \\
\hline \multicolumn{4}{|l|}{ Population agglomeration } \\
\hline Density of the poor & 1.26 & $1.13-1.40$ & 0.02 \\
\hline Population density & 1.24 & $1.12-1.38$ & 0.00 \\
\hline Households with more than three residents per room & 1.69 & $1.35-2.09$ & 0.00 \\
\hline \multicolumn{4}{|l|}{ Migration } \\
\hline Migrant between one and two years before the Census & 1.50 & $1.21-1.86$ & 0.00 \\
\hline Migrant for more than ten years before the Census & 0.75 & $0.53-1.07$ & 0.11 \\
\hline \multicolumn{4}{|l|}{ Multiple model } \\
\hline Households with private vehicles & 0.46 & $0.35-0.60$ & 0.00 \\
\hline Households with more than three residents per room & 1.39 & $1.10-1.76$ & 0.00 \\
\hline Households connected to the general sewage network & 1.29 & $1.96-2.66$ & 0.00 \\
\hline Households with open sewer in the surroundings & 1.42 & $1.22-1.66$ & 0.00 \\
\hline Density of the poor & 1.20 & $1.08-1.34$ & 0.00 \\
\hline Migrant between one and two years before the Census & 1.44 & $1.17-1.78$ & 0.00 \\
\hline Theil Index & 1.98 & $1.05-3.73$ & 0.00 \\
\hline
\end{tabular}

IRR: Incidence Rate Ratio

\section{DISCUSSION}

The remarkable relationship between the occurrence of tuberculosis and socioeconomic inequalities observed in this study highlights an important framework of social inequities in health, evidenced not only in our results, but also in other studies using different territorial units ${ }^{3,7,10,13}$.

The pattern of spatial distribution of tuberculosis for the study area can be the result of a socio-spatial reorganization, with the displacement of the low-income population to areas that lack health and housing infrastructure because of the increased real estate speculation ${ }^{\mathrm{b}, \mathrm{c}}$. The limits and scope of the local control program to reduce the rates in these new urban agglomerations in socioeconomic vulnerability situation should be assessed.

The higher incidence of tuberculosis in neighborhoods with higher coverage of the general sewage network in the study area suggests the existence of socio-spatial heterogeneity because of the presence of pockets of poorer populations in neighborhoods with better health infrastructure. Such aspect is reinforced by the higher incidence of tuberculosis in 
neighborhoods with greater inequality of income distribution (Theil index). This information points to the need of studies to be developed at the local level that can identify particular characteristics not captured or included in analyses of higher level of spatial aggregation ${ }^{14}$.

Although we have identified higher incidences of tuberculosis in neighborhoods with higher population density and higher density per room, these indicators do not always relate with the disease directly. The high concentration of persons in a given space does not necessarily mean poor living conditions, as discussed by Vicentin et al. ${ }^{18}$ (2002). The density of the poor proved to be more suitable as the marker of these spaces, as it aggregates individual and territorial attributes, indirectly measuring the rate of social contact from the densification of persons who live in situations of insecurity and who are less able to act/respond to tuberculosis ${ }^{2}$.

The higher incidence of tuberculosis in neighborhoods with higher percentage of beneficiaries of government cash transfer programs (Bolsa Familia and Program on the Elimination of Child Labor) suggests greater vulnerability because of the poverty or extreme poverty present in these areas.

Studies show positive effects of cash transfer programs on the health situation, with significant impacts on the reduction of inequality of income distribution in Brazil from 2000, as a result of the economic and social inclusion of families living in poverty ${ }^{17, h, i}$.

Although they grant improved nutritional status and greater access to health services ${ }^{11}$, in this sectional study the highest incidence of tuberculosis in neighborhoods with higher proportions of beneficiaries of these programs is present as a marker of poor living conditions and, ultimately, of the greater vulnerability to tuberculosis. For a better understanding of the impact of these programs on the occurrence of tuberculosis, we need to consider the percentage of coverage, time of implementation and interaction of those programs with the Family Health Strategy, as emphasized by Rosela et al. ${ }^{17}$ (2013).

The contribution of recent residents is estimated to be approximately $4.4 \%$ of the city population, comprising persons in economically active age (15 to 59 years). Although the contribution of immigrants to this city is not very intense, its occurrence suggests the influence of COMPERJ as an attractive hub and vector of organization of the territory. At the time of the initial implementation of the project, migration flows were low. However, a more significant contribution of immigrants may happen with the beginning of the operation of the refinery and installation of downstream petroleum industries, as in the city of Macaé, RJ, which experienced a process similar to what is happening in Itaboraí.

h Soares FV, Soares S, Medeiros M, Osorio R. Cash transfer programmes in Brazil: impacts on inequality and poverty. New York: United Nation Population Division; 2006. Available from: http://www.ideas.respec.org/ipc/ wpapper/21.html

iSantos LMP, Paes-Sousa R, Miazagi E, Silva TF, Fonseca AMM. The Brazilian experience with conditional cash transfers: a successful way to reduce inequity and improve health. World Conference of Determinants of Health; 19-21 Oct 2011; Rio de Janeiro.

¡Terra D, Ressiguier JH.

Mudanças no espaço urbano de Macaé: 1970-2010: Impactos sociais, ambientais e urbanos das atividades petrolíferas: o caso de Macaé. 2010; capítulo 2; p.149 [cited 2015 Oct 20]. Available from: http://www.uff.br/ macaeimpacto/OFICINAMACAE/ pdf/AZ_OficinalmpactosMacae TodosTextos.pdf

The higher incidence of tuberculosis in neighborhoods with higher proportion of recent immigrants is an important challenge to the disease control program of the city. The arrival of immigrants with low degree of technical training and little prospect of integration into the formal economy circuit results in the occupation of areas with worse housing conditions and reduced public services. These socio-spatial patterns imply a greater risk of exposure to tuberculosis. The great challenge of the local control program is the development and consolidation of a surveillance that can identify new urban spaces vulnerable to the disease.

The use of the neighborhood as unit of analysis could capture the relationship between socioeconomic inequalities and tuberculosis. However, the internal heterogeneity of these territorial units could not discriminate the presence of pockets of worse living conditions where actions to control tuberculosis could be intensified. Considering the relevance of the service to control tuberculosis, another limitation that could not be controlled in this study is the unavailability of an indicator that would measure the quality of the care of the FHS in each neighborhood, as the good coverage in the city does not necessarily mean adequate assistance to the cases of tuberculosis.

Our results corroborate the findings in other studies regarding the importance of socioeconomic determinants for tuberculosis, showing the disproportionate incidence of the disease among population groups with worse living conditions ${ }^{7,16,19}$. 
The implementation of an important vector of economic development in the study area provides a set of opportunities, stresses and vulnerabilities experienced in a rapidly changing territory. On the one hand, the implementation of this type of project generates opportunities for the Government to expand and improve housing, health, and education services because of the collection of taxes and royalties. On the other hand, the increase in socioeconomic inequalities and real estate speculation raises tensions and vulnerabilities related to the unequal appropriation of the territory, in which those with little economic power occupy neighborhoods with little public investment in housing infrastructure.

The collaboration of health services and other municipal public sectors focused on housing, infrastructure, social welfare, and education is very important to reduce the social burden of tuberculosis so that the problem is not solved solely based on the responsiveness of local disease control programs.

\section{REFERENCES}

1. Amaral D, Sánchez F, Bienenstein R. O leste fluminense, o COMPERJ e a questão urbano-habitacional. In: Oliveira FL, Cardoso AL, Costa HSM, Vainer CB, organizadores. Grandes projetos metropolitanos: Rio de Janeiro e Belo Horizonte. Rio de Janeiro (RJ): Letra Capital; 2012. p. 151-86.

2. Angelo JR, Toledo LM, Sabroza PC. Produção do espaço urbano e tuberculose no município de Juiz de Fora. In: Ramires JCL, organizador. Dinâmica socioespacial e saúde coletiva em cidades de Minas Gerais. Rio de Janeiro (RJ): Letra Capital; 2013. v. 1, p. 103-38.

3. Chan-yeung M, Yeh AG, Tam CM, Kam KM, Leung CC, YewWW et al. Socio-demographic and geographic indicators and distribution of tuberculosis in Hong Kong: a spatial analysis. Int J Tuberc Lung Dis. 2005;9(12):1320-6.

4. Dye C, Lönnroth K, Jaramillo E, Williams BG, Raviglione M. Trends in tuberculosis incidence and their determinants in 134 countries. Bull World Health Organ. 2009;87(9):683-91. https://doi.org/10.2471/BLT.08.058453

5. Leung CC, Yew WW, Tam CM, Chan CK, Chang KC, Law WS et al. Socioeconomic factors and tuberculosis: a district-base ecological analysis in Hong Kong. Int J Tuberc Lung Dis. 2004;8(8):958-64.

6. Ministério da Saúde, Secretaria de Vigilância em Saúde, Departamento de Vigilância de Doenças Transmissíveis. Panorama da tuberculose no Brasil: indicadores epidemiológicos e operacionais. Brasília (DF): Ministério da Saúde; 2014.

7. Molina Serpa I, López Pardo C, Alonso Hernandez R. Un estudio ecológico sobre tuberculosis en un municipio de Cuba. Cad Saude Publica. 2003;19(5):1305-12. https://doi.org/10.1590/S0102-311X2003000500009

8. Myers AL, Allore H, Gill TM, Peduzzi PN. Application of negative binomial modeling for discrete outcomes: a case study in aging research. J Clin Epidemiol. 2003;56:559564. https://doi.org/10.1016/S0895-4356(03)00028-3

9. Myers WP, Westenhouse JL, Flood J, Riley LW. An ecological study of tuberculosis transmission in California. Am J Public Health. 2006;96(4):685-90. https://doi.org/10.2105/AJPH.2004.048132

10. Oren E, Koepsell T, Leroux BG, Mayer J. Area-based socio-economic disadvantage and tuberculosis incidence. Int / Tuberc Lung Dis. 2012;16(7):880-5. https://doi.org/10.5588/ijtld.11.0700

11. Paes-Sousa R, Santos LMP, Miazaki ES. Effects of a conditional cash transfer programme on child nutrition in Brazil. Bull World Health Organ. 2011;89(7):496-503. https://doi.org/10.2471/BLT.10.084202

12. Pang PT, Leung CC, Lee SS. Neighbourhood risk factors for tuberculosis in Hong Kong. Int J Tuberc Lung Dis. 2010;14(5):585-92.

13. Ponticiello A, Sturkenboom MC, Simonetti A, Ortolani R, Malerba M, Sanduzzi A. Deprivation, immigration and tuberculosis incidence in Naples, 1996-2000. Eur J Epidemiol. 2005;20(8):729-34. https://doi.org/10.1007/s10654-005-0615-9

14. San Pedro A, Souza-Santos R, Sabroza PC, Oliveira RM. Condições particulares de produção e reprodução da dengue em nível local: estudo de Itaipu, Região Oceânica de Niterói, Rio de Janeiro, Brasil. Cad Saude Publica. 2009;25(9):1937-46. https://doi.org/10.1590/S0102-311X2009000900008 
15. San Pedro A, Oliveira R. Tuberculose e indicadores socioeconômicos: revisão sistemática da literatura. Rev Panam Salud Publica. 2013;33(4):294-301. https://doi.org/10.1590/S1020-49892013000400009

16. Silva DF, Pereira MJF. Reestruturação do modelo de atenção do Programa de Controle de Tuberculose do município de Itaboraí, Rio de Janeiro. J Bras Pneumol. 2008;34 supl:1-70

17. Rosela D, Aquino A, Santos CAT, Paes-Sousa R, Barreto ML. Effect of a conditional cash transfer programme on childhood mortality: a nationwide analysis of Brazilian municipalities. Lancet. 2013;382(9886):57-64. https://doi.org/10.1016/S0140-6736(13)60715-1

18. Vincentin G, Santo AH, Carvalho MS. Mortalidade por tuberculose e indicadores sociais no município do Rio de Janeiro. Cienc Saude Coletiva. 2002;7(2):253-63. https://doi.org/10.1590/S1413-81232002000200006

19. Ximenes RAA, Albuquerque MFPM, Souza WV, Montarroyos UR, Diniz GTN, Luna CF et al. Is it better to be rich in a poor area or a poor in a rich area? A multilevel analysis of a case-control study of social determinants of tuberculosis. Int J Epidemiol. 2009;38(5):1285-96. https://doi.org/10.1093/ije/dyp224

Authors' Contribution: Design and planning of the study: ASP, RMO, PCS. Analysis and interpretation of the data: ASP, GG, JPCS. Drafting of the study: ASP, GG. Critical review of the study: ASP, LMT, RMO, GG.

Conflict of Interest: The authors declare no conflict of interest. 